\title{
Antibacterial Activity of Ethanolic Extract of Syzygium polyanthum L. (Salam) Leaves against Foodborne Pathogens and Application as Food Sanitizer
}

\author{
Suzita Ramli, ${ }^{1}$ Son Radu, ${ }^{1}$ Khozirah Shaari, ${ }^{2}$ and Yaya Rukayadi ${ }^{1,2}$ \\ ${ }^{1}$ Department of Food Science, Faculty of Food Science and Technology, Universiti Putra Malaysia (UPM), 43400 Serdang, \\ Selangor, Malaysia \\ ${ }^{2}$ Laboratory of Natural Products, Institute of Bioscience, Universiti Putra Malaysia (UPM), 43400 Serdang, Selangor, Malaysia
}

Correspondence should be addressed to Yaya Rukayadi; yaya_rukayadi@upm.edu.my

Received 19 August 2017; Revised 31 October 2017; Accepted 19 November 2017; Published 19 December 2017

Academic Editor: Nikos Chorianopoulos

Copyright (C) 2017 Suzita Ramli et al. This is an open access article distributed under the Creative Commons Attribution License, which permits unrestricted use, distribution, and reproduction in any medium, provided the original work is properly cited.

\begin{abstract}
The aim of this study was to determine antibacterial activity of $S$. polyanthum L. (salam) leaves extract foodborne pathogens. All the foodborne pathogens were inhibited after treating with extract in disk diffusion test with range $6.67 \pm 0.58-9.67 \pm 0.58 \mathrm{~mm}$ of inhibition zone. The range of MIC values was between 0.63 and $1.25 \mathrm{mg} / \mathrm{mL}$ whereas MBC values were in the range $0.63 \mathrm{mg} / \mathrm{mL}$ to $2.50 \mathrm{mg} / \mathrm{mL}$. In time-kill curve, L. monocytogenes and P. aeruginosa were found completely killed after exposing to extract in $1 \mathrm{~h}$ incubation at $4 \mathrm{x}$ MIC. Four hours had been taken to completely kill E. coli, S. aureus, V. cholerae, and V. parahaemolyticus at 4x MIC. However, the population of K. pneumoniae, P. mirabilis, and S. typhimurium only reduced to $3 \log$ CFU/mL. The treated cell showed cell rupture and leakage of the cell cytoplasm in SEM observation. The significant reduction of natural microflora in grapes fruit was started at $0.50 \%$ of extract at $5 \mathrm{~min}$ and this concentration also was parallel to sensory attributes acceptability where application of extract was accepted by the panellists until 5\%. In conclusion, S. polyanthum extract exhibits antimicrobial activities and thus might be developed as natural sanitizer for washing raw food materials.
\end{abstract}

\section{Introduction}

Food safety is a major concern for both consumers and food manufacturers alike. Despite the high degree of awareness of food preservation methods, the occurrence of disease outbreaks caused by foodborne pathogens and spoilage microorganisms in foods is still increasing [1]. Foodborne illness is also known as foodborne disease and colloquially referred to food poisoning is any illness resulting from the consumption of contaminated food, pathogenic bacteria, viruses, or parasites that contaminate food, rather than chemical or natural toxins. The symptoms for food poisoning are including diarrhea, fever, vomiting, abdominal pain, and dehydration [2]. Currently to preserve food from spoilage, some manufacturers used synthetic antimicrobial agents to prevent the growth of food spoilage and food pathogenic microorganisms include benzoates, nitrates, and nitrites
[3]. However, emergence of microbial resistance to classic antimicrobial agents becomes a major health concern due to elevated use of chemical preservatives in food processing [4]. Nowadays, consumers are more aware on food safety especially on the long term effect of synthetic additives in food including toxic and carcinogenic effect. Hence, this issue has led to the increased demand for high-quality, minimally processed foods with extended shelf-life and preferably free from or with a low level of synthetic additives in food [5]. Moreover, foods need to be safe and fresh with prolonged shelf-life. Therefore, antimicrobials agent from natural plants is a good source as an alternative to synthetic preservatives in order to satisfy consumers demand for safe and healthy food [6]. Antimicrobial agents can be either synthesized or naturally occurring in plant materials [7]. The main reasons for adding antimicrobial in food are to control food spoilage and to prevent the growth of foodborne pathogens 
[8]. This suggests that natural plants might be sources of antimicrobials agents that can be used to inhibit the growth of foodborne pathogens.

S. polyanthum L., which is synonym to salam, is a deciduous tropical tree belonging to the Myrtaceae family [9]. This plant grows wildly on lowlands and is widely distributed in the temperate, subtropical, and tropical regions in the world [10]. These leaves had several name based on the location including $S$. polyanthum in Malaysia and Indonesia it is called serai kayu (Malay); meselangan is the name that used in Sumatra, gowok (Sunda), salam (Java, Sunda, Madura), manting (Java), or kastolam (Kangean) [11]. S. polyanthum leaves have been used traditionally as medicine or therapeutic agents including efficiency against ulcer, hypertension, diabetes, hyperuricemia, diarrheal, gastritis, skin diseases, and inflammation [11, 12]. Furthermore, S. polyanthum leaves were believed to possess antibacterial activity against Streptococcus mutans [11] and Staphylococcus aureus [13]. Besides that, this plant also had antifungal activities against spoilage fungi Euroticum spp., Aspergillus spp., and Penicillium spp. [14]. Furthermore, according to Perumal et al. [10], S. polyanthum leaves are also found to be noncytotoxic to normal mammalian cell lines. Based on previous study, $S$. polyanthum leaves had antibacterial activity against $B$. cereus and $B$. subtilis [15].

Therefore the aim of this study was to determine the antimicrobial activity of $S$. polyanthum leaves extracts against a wide spectrum of foodborne pathogens.

\section{Materials and Methods}

2.1. Samples. Dried S. polyanthum leaves were purchased from Herbal Market Bandung, Indonesia, deposited, and identified in Institute of Bioscience (IBS), Universiti Putra Malaysia.

2.2. Preparation of Extract. One hundred grams of dried $S$. polyanthum leaves was ground using dry blender. Then, the samples were soaked in $400 \mathrm{~mL}$ absolute ethanol for seven days at room temperature as stated by Rukayadi et al. [16], with some modification. The mixture was then filtered using Whatman number 2 filter paper and concentrated by using rotary evaporator at $50^{\circ} \mathrm{C}$ and at speed of $150 \mathrm{rpm}$ for 60 to $90 \mathrm{~min}$. The extract was dissolved in $10 \%$ dimethylsulfoxide (DMSO) to obtain stock solution. The final concentration of extract was standardized at $10 \mathrm{mg} / \mathrm{mL}$ or $1 \%$. The stock solution was kept at $-4^{\circ} \mathrm{C}$.

2.3. Bacteria Cultures. A total of nine strains of frequently reported as foodborne pathogens were included: Escherichia coli O157:H7 ATCC 43895, Klebsiella pneumoniae ATCC 13773, Listeria monocytogenes ATCC 19112, Proteus mirabilis ATCC 21100, Pseudomonas aeruginosa ATCC 9027, Salmonella typhimurium ATCC 14028, Staphylococcus aureus ATCC 29737, Vibrio cholerae (Isolate 2), and Vibrio parahaemolyticus ATCC 1780. All the microbial strains used in this study were maintained by subculturing them on the nutrient agar (NA) or nutrient agar mix with $3 \%$ of $\mathrm{NaCl}$ for $V$. cholerae and $V$. parahaemolyticus and were incubated overnight. Bacteria strains can be stored in this way for a few weeks on the agar plates before subculturing them again, while, for the stock culture preparation, $0.5 \mathrm{~mL}$ of overnight culture with broth media was mixed into $0.5 \mathrm{~mL}$ of $80 \%$ sterile glycerol. Cultures were stored at $-20^{\circ} \mathrm{C}$. These stock cultures were kept from 6 months to 1 year [17].

2.4. Disk Diffusion Test. S. polyanthum extract was tested for antimicrobial activity using the disk diffusion method as described by CLSI [18]. Bacteria species with concentration in range $10^{6}-10^{8} \mathrm{CFU} / \mathrm{mL}$ were spread on Mueller Hinton agar (MHA) with a sterile cotton swab. Sterile filter paper discs with $6 \mathrm{~mm}$ diameter were placed on top of the culture and $10 \mu \mathrm{L}$ of $10 \mathrm{mg} / \mathrm{mL}(\mathrm{w} / \mathrm{v})$ of $S$. polyanthum leaves extract was loaded on the paper discs. $0.1 \%$ of commercial chlorhexidine (CHX) was used as positive control whereas 10\% DMSO as negative control. The plates were incubated at $37^{\circ} \mathrm{C}$ for 24 hours. Evidence of clear zone indicates bacterial growth inhibition and the diameter was measured in $\mathrm{mm}$.

\subsection{Determination of Minimum Inhibitory Concentration} (MIC) and Minimum Bactericidal Concentration (MBC). Determination of MIC and MBC values was performed using a method described in the CLSI [18]. MIC was conducted in 96-well U-shaped microtiter plate using twofold standard broth microdilution method with an inoculum of approximately $10^{6}-10^{8} \mathrm{CFU} / \mathrm{mL}$. S. polyanthum leaves extract with concentration $10 \mathrm{mg} / \mathrm{mL}$ was mixed and twofold diluted in the respective medium containing inoculum. Column 12 of the microtiter plate contained the highest concentration of extract $(5 \mathrm{mg} / \mathrm{mL})$ while column 3 contained the lowest concentration of extract $(0.0097 \mathrm{mg} / \mathrm{mL})$. Column 1 served as negative control (only medium, no inoculum, and no antimicrobial agent), while column 2 served as positive control for all samples (only medium and inoculum or antimicrobial agent-free well) for 24 hours. The MIC was defined as the lowest concentration of antimicrobial agent that was able to inhibit the visible growth [16] while minimal bactericidal concentration (MBC) was standing for the lowest concentration of antimicrobial agent that completely killed the growth of culture. MBC was determined by subculturing the suspension $(10 \mu \mathrm{L})$ from each well in microtiter plate on MHA. The plates were then incubated at $37^{\circ} \mathrm{C}$ for 24 hours or until growth was seen at positive control.

2.6. Time-Kill Curve Assay. A time-kill curve assay was carried out with the MIC values found previously in the microplate bioassay, using a modification of the viable cells count method of de Souza et al. [19]. S. polyanthum leaves extract was diluted with the Muller Hinton broth (MHB) medium containing inoculum of approximately $10^{6}-10^{8} \mathrm{CFU} / \mathrm{mL}$ to obtain final concentrations of $0 \mathrm{x} \mathrm{MIC}$, $0.5 \mathrm{x}$ MIC, $1 \mathrm{x}$ MIC, 2x MIC, and 4x MIC for each bacterial species. At different time intervals of exposure, $(0,0.5,1,2$, and 4 hours), $0.1 \mathrm{~mL}$ of the suspension was serially diluted in $1 \%$ phosphate buffered saline (PBS) and plated onto MHA. The plates were incubated at $37^{\circ} \mathrm{C}$ for 24 hours. The results were expressed in $\log \mathrm{CFU} / \mathrm{mL}$. 
TABLE 1: Inhibition zone of S. polyanthum L. leaves extract against foodborne pathogens.

\begin{tabular}{|c|c|c|c|}
\hline \multirow{2}{*}{ Strains } & \multicolumn{3}{|c|}{ Inhibition zone (mm) } \\
\hline & S. polyanthum extract & $\mathrm{CHX}$ & DMSO \\
\hline E. coli $\mathrm{O} 157: \mathrm{H} 7$ & $7.00 \pm 0.28$ & $9.00 \pm 0.00$ & n.a \\
\hline K. pneumoniae & $9.33 \pm 0.50$ & $11.50 \pm 0.50$ & n.a \\
\hline L. monocytogenes & $9.67 \pm 0.58$ & $12.00 \pm 0.00$ & n.a \\
\hline P. aeruginosa & $7.00 \pm 0.32$ & $10.00 \pm 0.51$ & n.a \\
\hline P. mirabilis & $6.67 \pm 0.40$ & $10.00 \pm 0.70$ & n.a \\
\hline S. aureus & $9.33 \pm 0.52$ & $10.00 \pm 0.23$ & n.a \\
\hline S. typhimurium & $6.67 \pm 0.50$ & $8.00 \pm 0.00$ & n.a \\
\hline$V$. cholerae & $8.33 \pm 0.30$ & $8.80 \pm 0.58$ & n.a \\
\hline V.parahaemolyticus & $6.67 \pm 0.50$ & $9.00 \pm 0.00$ & n.a \\
\hline
\end{tabular}

n.a: no activity; diameter of inhibition zones in $\mathrm{mm}$ (including disc); positive control (chlorhexidine: CHX; 0.1\%); negative control (DMSO; 10\%); results were expressed as means \pm standard deviation $(\mathrm{SD}) ; n=3 \times 3$.

2.7. Scanning Electron Microscope (SEM). Fresh K. pneumoniae and $S$. aureus culture was treated with the extract and incubated at $37^{\circ} \mathrm{C}$ in $\mathrm{MHB}$ for 24 hours. The pellets were collected by centrifugation $(5000 \times \mathrm{g}$ for $10 \mathrm{~min})$ and were fixed with $2.5 \%$ glutaraldehyde for $4-6$ hours at $4^{\circ} \mathrm{C}$. Then, the pellets were washed with $0.1 \mathrm{M}$ sodium cacodylate buffer for $10 \mathrm{~min}$ and were repeated for 3 times. The pellets were then postfixed with $1 \%$ osmium tetroxide for 2 hours at $4^{\circ} \mathrm{C}$, washed again with $0.1 \mathrm{M}$ sodium cacodylate buffer for $10 \mathrm{~min}$, and repeated for 3 times. Then the pellets were dehydrated using $35,50,75$, and $95 \%$ acetone for 15 min each. Lastly the pellets were dehydrated using $100 \%$ acetone for $15 \mathrm{~min}$ and were repeated for 3 times. Cell suspensions were transferred into a specimen basket, made from aluminium foil coated with albumin, and then put in critical dryer for 0.5 hours. The specimens were mounted on a stub and the sputter was coated with gold. The morphology of the cells was observed and images were obtained using SEM instrument.

\subsection{Application of S. polyanthum Extract as Food Sanitizer} on Grapes. The samples of grapes fruit (approximately $10 \mathrm{~g}$ ) were treated with tap water and natural sanitizer with concentration of $0.05 \%, 0.50 \%, 1.00 \%$, and $5.00 \%$ of S. polyanthum extract according to Yusoff et al. [20] with slight modification. Grapes fruit was soaked separately at different time interval, 5,10 , and $15 \mathrm{~min}$, to determine their microflora growth viability. Untreated samples remained unwashed. For bacteria growth determination, $1 \mathrm{~mL}$ from each treatment was diluted into $10^{-1}, 10^{-2}$, and $10^{-3}$ dilution. Then, $0.1 \mathrm{~mL}$ from each dilutions series was spread on the different types of agar, Plate count agar, Eosin Methylene Blue agar (EMB), and Baird Parker agar, and incubated at $37^{\circ} \mathrm{C}$ for 24 hours. The presence of colonies was counted.

\subsection{Evaluation of Sensory Attributes Acceptability of Treated} Grapes Fruit. The sensory evaluation acceptability test was performed according to Brasil et al. [21], with slight modification. A group of 50 untrained panellists were presented with five different 3-digit coded samples placed in a random order. The evaluation was conducted based on the 9point hedonic scale for inspection acceptance testing where panellists assessed each treated sample in terms of colour (observed with eyes), odour (smelled with nose), and the texture (touched with finger). The ratings for the each analysis of samples were given in a scale ranging from extremely disliked (scale of 1) to extremely liked (scale of 9).

\section{Results}

3.1. Yield of Extract. $100 \mathrm{~g}$ of dried weight of S. polyanthum leaves was extracted using ethanol solvent and yielded $8.21 \mathrm{~g}$ of extract, which gave the percentage value of $8.21 \%$ total yield.

3.2. Disk Diffusion Test. The inhibition zone of S. polyanthum leaves extract against foodborne pathogens is shown in Table 1. The inhibition zones were between $6.67 \pm 0.58$ and $9.67 \pm 0.58 \mathrm{~mm}$. Results showed the inhibition zones of $S$. polyanthum extract were $7.00 \pm 0.28 \mathrm{~mm}, 9.33 \pm 0.50 \mathrm{~mm}$, $9.67 \pm 0.58 \mathrm{~mm}, 7.00 \pm 0.32 \mathrm{~mm}, 6.67 \pm 0.58 \mathrm{~mm}, 9.33 \pm$ $0.58 \mathrm{~mm}, 6.67 \pm 0.50 \mathrm{~mm}, 8.33 \pm 0.58 \mathrm{~mm}$, and $6.67 \pm 0.58 \mathrm{~mm}$ on E. coli, K. pneumoniae, L. monocytogenes, P. aeruginosa, P. mirabilis, S. aureus, S. typhimurium, V. cholerae, and V. parahaemolyticus, respectively. The larger inhibition zone gave the meaning of higher antibacterial activity of the extract on the tested microbial species.

\subsection{Determination of Minimum Inhibitory Concentration} (MIC) and Minimum Bactericidal Concentration (MBC). From the result shown in Table 2, S. polyanthum leaves extract demonstrated broad-spectrum activity against all selected bacteria with the MIC values ranging from 0.63 to $1.25 \mathrm{mg} / \mathrm{mL}$. Among them L. monocytogenes and S. aureus were found to be the most susceptible pathogens with the MIC value of $0.63 \mathrm{mg} / \mathrm{mL}$. Results show that the MBC was in the range of $0.63 \mathrm{mg} / \mathrm{mL}$ to $2.50 \mathrm{mg} / \mathrm{mL}$. L. monocytogenes gave the lower $\mathrm{MBC}$ value compared to other strains which was $0.63 \mathrm{mg} / \mathrm{mL}$.

3.4. Time-Kill Curve Assay. In this study, time-killing assay was done to find the correlation between the concentrations of S. polyanthum leaves extract with its killing effects on 


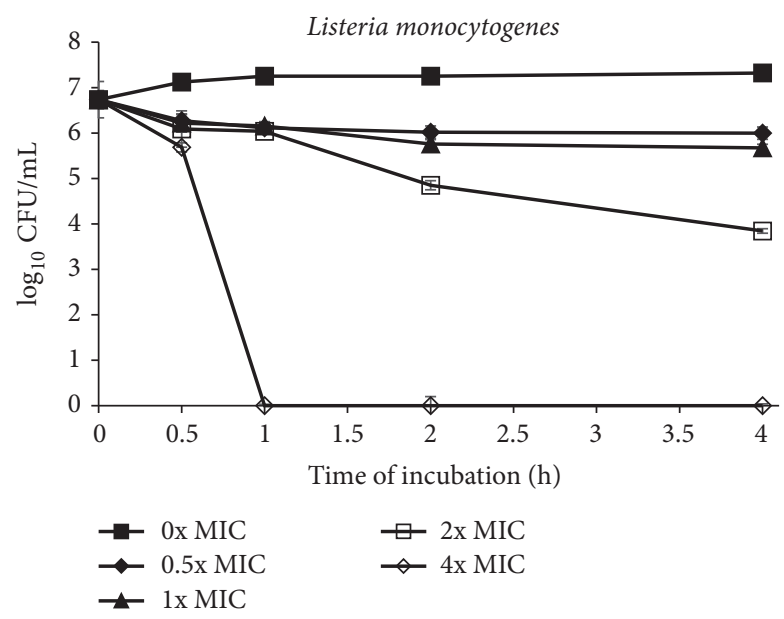

(a)

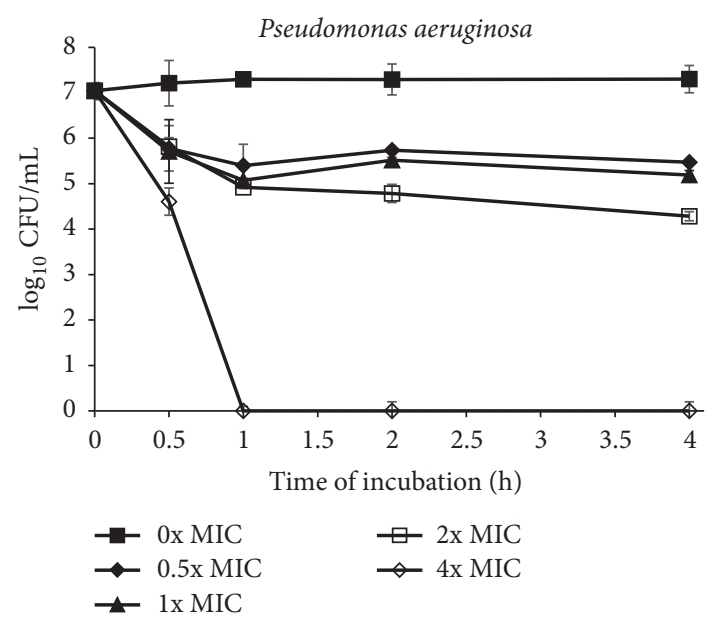

(b)

Figure 1: (a) Time-kill curve plots for L. monocytogenes $(0,0.315,0.630,1.260$, and $2.520 \mathrm{mg} / \mathrm{mL})$ following exposure to S. polyanthum L. extract. Values given in the brackets after species are $0 \mathrm{x}$ MIC, $0.5 \mathrm{x}$ MIC, $1 \mathrm{x}$ MIC, $2 \mathrm{x}$ MIC, and $4 \mathrm{x}$ MIC, respectively. (b) Time-kill curve plots for $P$. aeruginosa $(0,0.625,1.250,2.500$, and $5.000 \mathrm{mg} / \mathrm{mL})$ following exposure to $S$. polyanthum L. extract. Values given in the brackets after species are 0x MIC, 0.5x MIC, $1 \mathrm{x}$ MIC, 2x MIC, and 4x MIC, respectively.

TABLE 2: Minimum inhibitory concentration (MIC) and minimum bactericidal concentration (MBC) of S. polyanthum L. extract against foodborne pathogens.

\begin{tabular}{lcc}
\hline Strains & MIC $(\mathrm{mg} / \mathrm{mL})$ & $\mathrm{MBC}(\mathrm{mg} / \mathrm{mL})$ \\
\hline E. coli O157:H7 & 1.25 & 2.50 \\
K. pneumoniae & 1.25 & 2.50 \\
L. monocytogenes & 0.63 & 0.63 \\
P. aeruginosa & 1.25 & 2.50 \\
P. mirabilis & 1.25 & 2.50 \\
S. aureus & 0.63 & 1.25 \\
S. typhimurium & 1.25 & 1.25 \\
V. cholerae & 1.25 & 1.25 \\
V. parahaemolyticus & 1.25 & 1.25 \\
\hline
\end{tabular}

selected foodborne pathogens. Time-kill curve assay showed that $S$. polyanthum leaves extract can kill $L$. monocytogenes and P. aeruginosa at 4x MIC for 1 hour (Figures 1(a) and 1(b)) and E. coli, S. aureus, V. cholerae, and V. parahaemolyticus at 4x MIC for 4 hours (Figures 2(a), 2(b), 2(c), and 2(d)). The population of K. pneumoniae, P. mirabilis, and S. typhimurium also showed a reduction $<3 \log _{10} \mathrm{CFU} / \mathrm{mL}$ when treated with the extract at $4 \mathrm{x}$ MIC for 4 hours as shown in Figures 3(a), $3(b)$, and 3(c).

3.5. Scanning Electron Microscope (SEM). Figures 4(a) and 4(b) show the treated and untreated K. pneumoniae cells with S. polyanthum extract at the concentration of $1.25 \mathrm{mg} / \mathrm{mL}$ for overnight. The untreated K. pneumoniae showed normal cells characteristics with rod shape and intact peptidoglycan layer. Meanwhile, after treating with S. polyanthum extract overnight, cells appeared to be damaged with some irregularities surfaces, whereby the rod-shaped cells shrank and deflated, and some of them were cavitated. Besides that, the effect of $S$. polyanthum extract against $S$. aureus is shown in Figures 5(a) and 5(b). The grape-like cluster morphology of $S$. aureus was altered after the treatment. Disruptions with release of intracellular material associated with S. aureus cells losing their cytoplasm (empty and flaccid cells) were also observed.

3.6. Application of S. polyanthum Extract as Food Sanitizer on Grapes. Table 3 shows the effect of $S$. polyanthum against natural flora in grapes. Bacterial population which was detected in grapes includes E. coli and S. aureus. This study showed that total plate count had been reduced significantly after exposure to $0.50 \%$ at $5 \mathrm{~min}$ soaking where the population decreased from $5.78 \pm 0.05$ to $5.19 \pm 0.13 \log _{10} \mathrm{CFU} / \mathrm{mL}$. On the other hand, E. coli's population only had been significantly reduced after treating at $1.00 \%$ for $5 \mathrm{~min}$ and decreased to undetected at $5 \%$ extract at $5 \mathrm{~min}$ treatment while $S$. aureus decreased to $\log _{10} 0.00 \pm 0.00 \mathrm{CFU} / \mathrm{mL}$ starting at $0.50 \%$ in $5 \mathrm{~min}$.

3.7. Evaluation of Sensory Attributes Acceptability of Treated Grapes Fruit. Table 4 shows the sensory acceptability of treated grapes with S. polyanthum extract. Based on the result, it can be concluded that most panellists accepted these grapes samples which were washed with extracts and tap water with overall acceptability of more than scale 7. There is also no significant difference between washing treatment using highest concentrations of extract (5\%) and tap water. That means that panellist is not able to differentiate between using tap water and extracts. Therefore, S. polyanthum did not affect the physical appearances of grapes. 


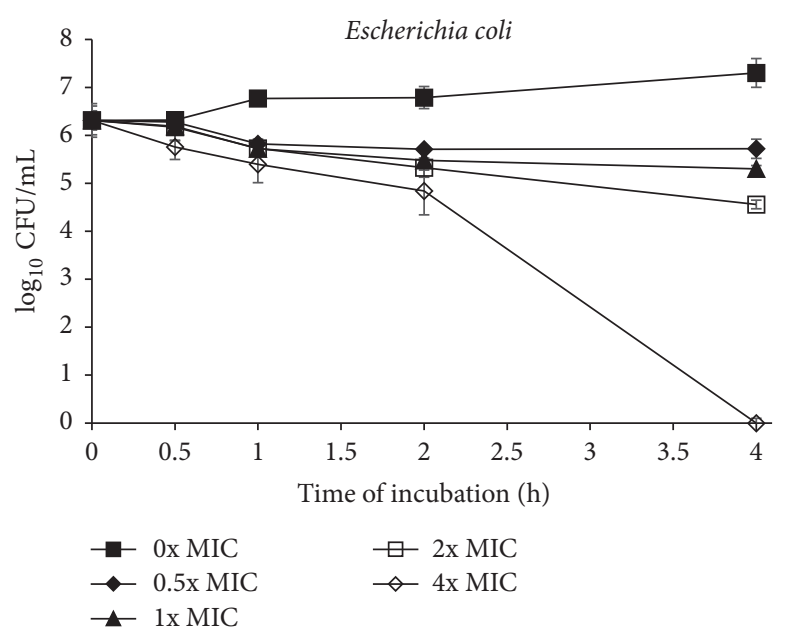

(a)

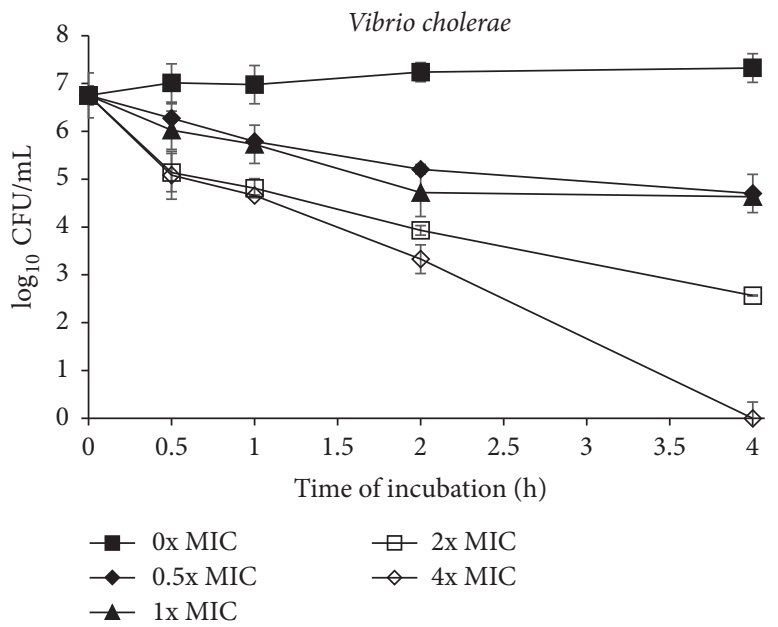

(c)

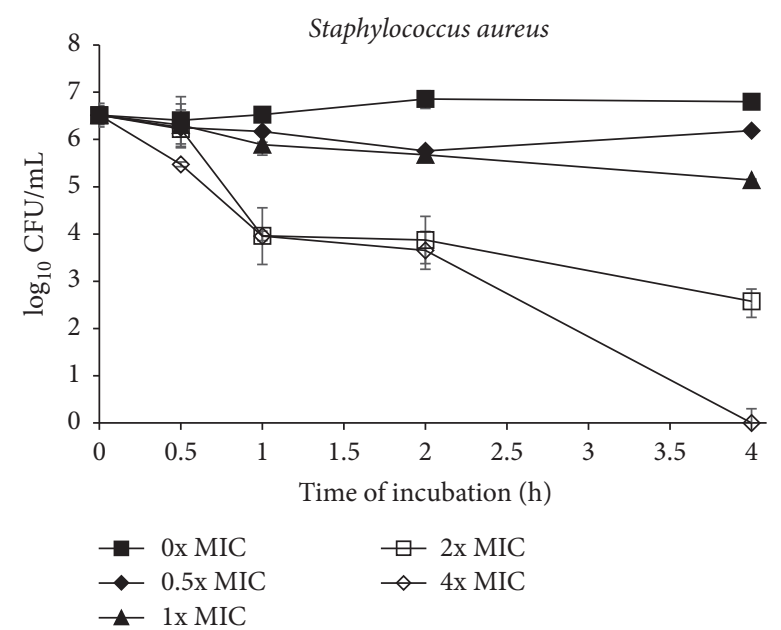

(b)

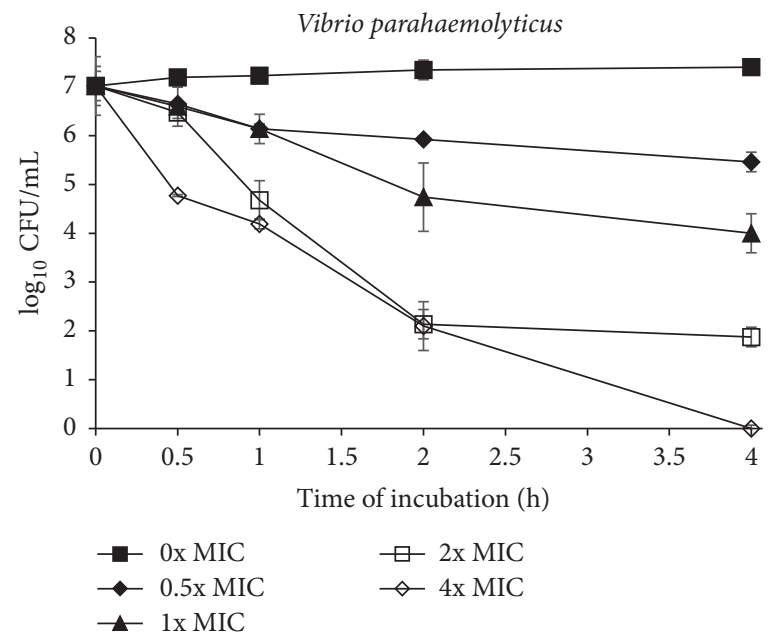

(d)

Figure 2: (a) Time-kill curve plots for E. coli $\mathrm{O} 157: \mathrm{H} 7(0,0.625,1.250,2.500$, and $5.000 \mathrm{mg} / \mathrm{mL})$ following exposure to S. polyanthum L. extract. Values given in the brackets after species are 0x MIC, $0.5 \mathrm{x}$ MIC, $1 \mathrm{x}$ MIC, $2 \mathrm{x}$ MIC, and 4x MIC, respectively. (b) Time-kill curve plots for S. aureus $(0,0.315,0.630,1.260$, and $2.520 \mathrm{mg} / \mathrm{mL})$ following exposure to S. polyanthum L. extract. Values given in the brackets after species are $0 \mathrm{x}$ MIC, $0.5 \mathrm{x}$ MIC, $1 \mathrm{x}$ MIC, $2 \mathrm{x}$ MIC, and 4x MIC, respectively. (c) Time-kill curve plots for V. cholerae $(0,0.625,1.250,2.500$, and $5.000 \mathrm{mg} / \mathrm{mL}$ ) following exposure to $S$. polyanthum L. extract. Values given in the brackets after species are $0 \mathrm{x}$ MIC, $0.5 \mathrm{x}$ MIC, $1 \mathrm{x}$ MIC, $2 \mathrm{x}$ MIC, and 4x MIC, respectively. (d) Time-kill curve plots for $V$. parahaemolyticus $(0,0.625,1.250,2.500$, and $5.000 \mathrm{mg} / \mathrm{mL})$ following exposure to S. polyanthum L. extract. Values given in the brackets after species are $0 \mathrm{x}$ MIC, $0.5 \mathrm{x}$ MIC, $1 \mathrm{x}$ MIC, $2 \mathrm{x}$ MIC, and 4x MIC, respectively.

\section{Discussion}

A recent trend in food processing is to avoid the use of chemical preservatives. Thus, natural antimicrobial alternatives are required. In this research, ethanol was used as a solvent. Ethanol is also classified as a polar solvent. This means that this solvent is miscible in water and it will extract mostly the ionic compounds from S. polyanthum leaves. Ethanol has better dissolving capabilities compared to water because it has a slightly low dipole and is dielectric; thus it is slightly polar [22]. Moreover, according to Marriott [23], the solvents permitted for use in the preparation of food ingredients are ethanol, ethyl acetate, and acetone only.

From the disk diffusion result, L. monocytogenes gave the highest inhibition zone compared to others strain. On the other hand, P. mirabilis, S. typhimurium, and V. parahaemolyticus were observed to be more resistant against the extract. Generally, in Gram-negative bacteria, their outer membranes serve as permeability barrier which allows only small hydrophilic molecules to pass through into the cell, restricting their rate of penetration for certain antimicrobial compounds and excluding larger molecules. Besides, they also possess multidrug resistant pumps which exclude some of the antibacterial compounds across the barrier [24]. These special buildings make the Gram-negative bacteria more tolerant to any foreign compounds intake. On the other hand, disk diffusion test sometimes gave inaccurate result due to some limitations such as the ability of extract to pass through the pore discs and the inability of hydrophobic compounds to diffuse into the media agar [25]. In addition according 


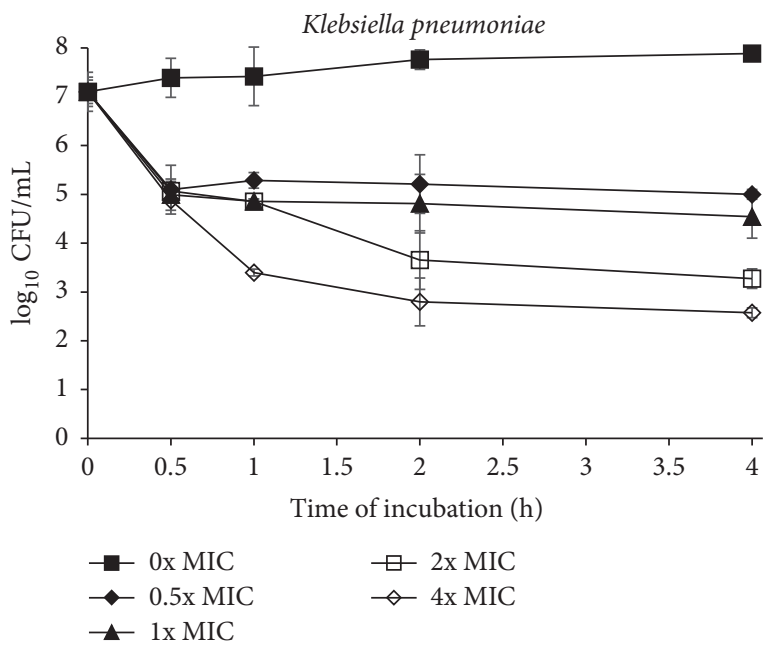

(a)

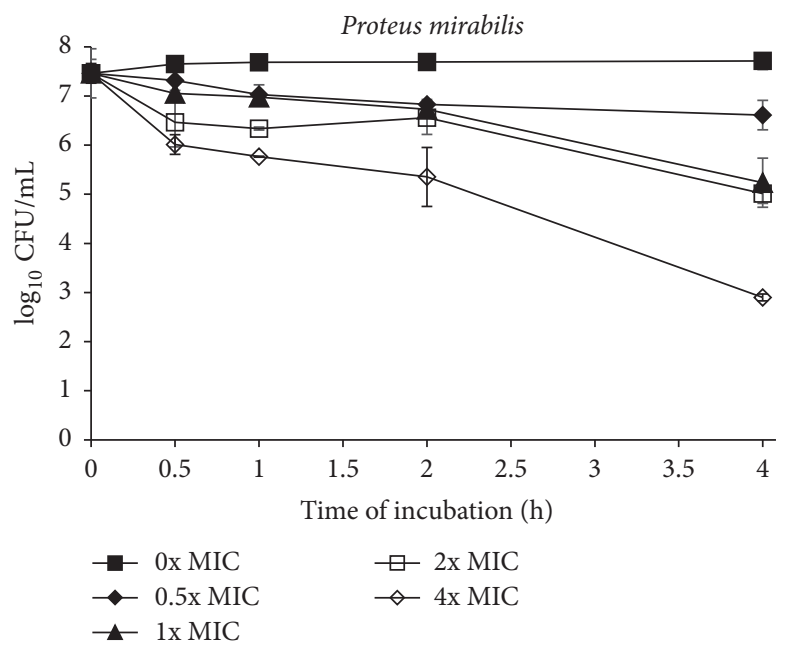

(b)

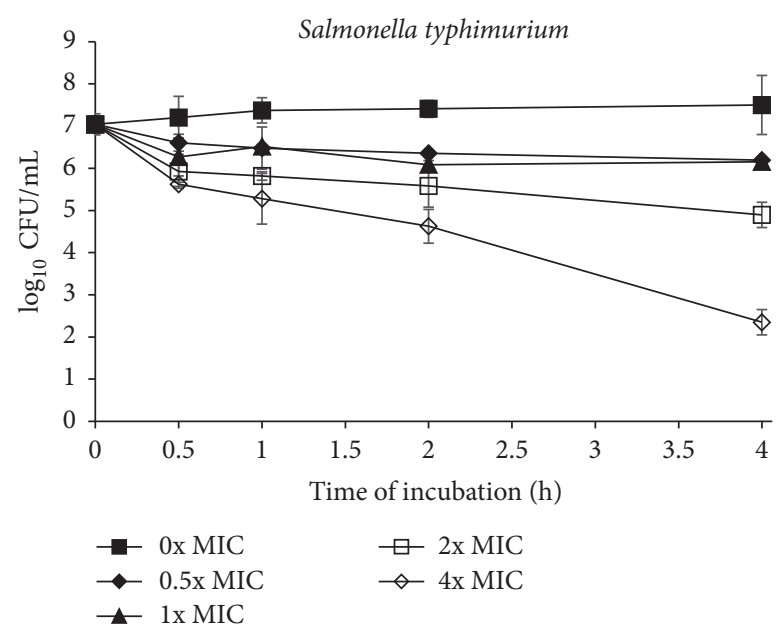

(c)

Figure 3: (a) Time-kill curve plots for $K$. pneumoniae $(0,0.625,1.250,2.500$, and $5.000 \mathrm{mg} / \mathrm{mL})$ following exposure to $S$. polyanthum L. extract. Values given in the brackets after species are $0 \mathrm{x}$ MIC, $0.5 \mathrm{x}$ MIC, $1 \mathrm{x}$ MIC, $2 \mathrm{x}$ MIC, and 4x MIC, respectively. (b) Time-kill curve plots for P. mirabilis $(0,0.625,1.250,2.500$, and $5.000 \mathrm{mg} / \mathrm{mL})$ following exposure to $S$. polyanthum L. extract. Values given in the brackets after species are 0x MIC, 0.5x MIC, 1x MIC, 2x MIC, and 4x MIC, respectively. (c) Time-kill curve plots for S. typhimurium (0, 0.625, 1.250, 2.500, and $5.000 \mathrm{mg} / \mathrm{mL}$ ) following exposure to S. polyanthum L. extract. Values given in the brackets after species are 0x MIC, $0.5 \mathrm{x}$ MIC, 1x MIC, 2x MIC, and 4x MIC, respectively.

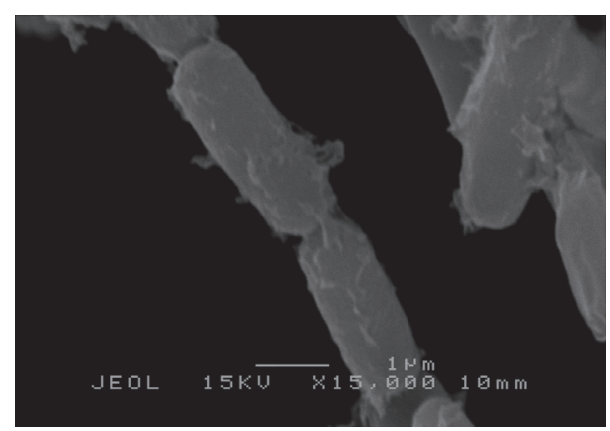

(a)

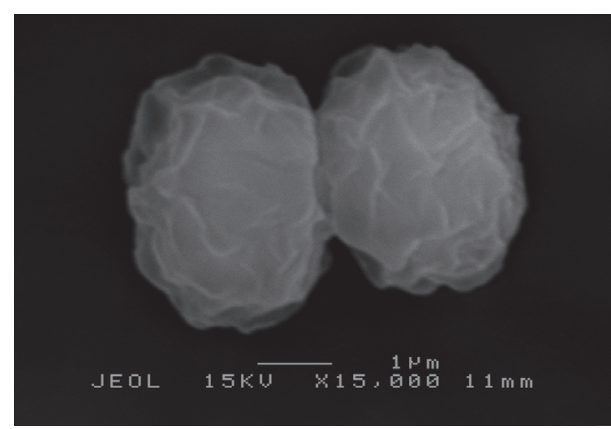

(b)

FIGURE 4: (a) Scanning electron micrograph of untreated K. pneumoniae. (b) Scanning electron micrograph of K. pneumoniae after treating with S. polyanthum L. extract at MIC value for 24 hours. 


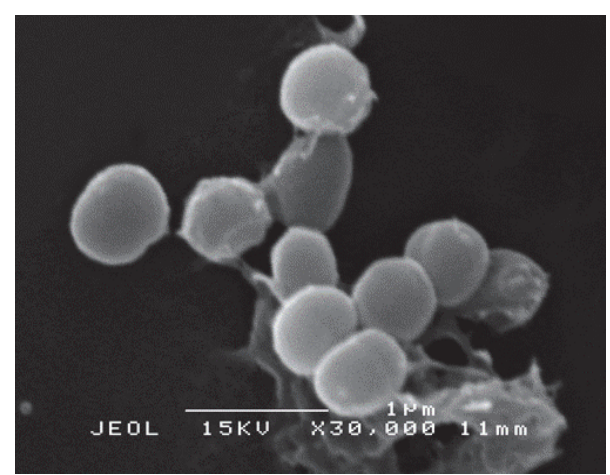

(a)

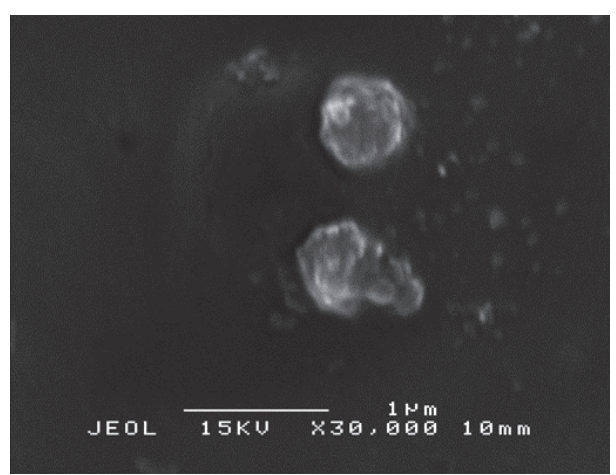

(b)

Figure 5: (a) Scanning electron micrograph of untreated S. aureus. (b) Scanning electron micrograph of $S$. aureus after treating with $S$. polyanthum L. extract at MIC value for 24 hours.

to Gangoué-Piéboji et al. [26], by using disc, some active compounds might be blocked in the disc pores and are unable to pass through the inoculated media and hence cannot express their activity. Besides that, inhibition zone of $0.1 \%$ of $\mathrm{CHX}$ against the pathogens was in range of $8.80 \pm 0.58$ to $12.00 \pm 0.00 \mathrm{~mm}$. This finding showed lower inhibition zone compared to the study done by Abbas et al. [27], which mentions that the inhibition zone was between $13.84 \pm 0.65$ and $14.87 \pm 0.53 \mathrm{~mm}$ on E. faecalis by using $2 \%$ of $\mathrm{CHX}$. This observation may be due to the different concentration of CHX. However, according to Gupta et al. [28], inhibition zone of CHX against $P$. aeruginosa was $10.00 \mathrm{~mm}$, whereas $S$. aureus was $11.00 \mathrm{~mm}$. Therefore, the finding was similar to this present study. In conclusion, the disc-diffusion test is normally used as first screening in the detection of active compounds in plant extracts before further determination was performed.

L. monocytogenes and $S$. aureus were found to be the most susceptible pathogen with the MIC value of $0.63 \mathrm{mg} / \mathrm{mL}$ while the other strains showed $1.25 \mathrm{mg} / \mathrm{mL}$. L. monocytogenes also showed the lower MBC values compared to other strains with $0.63 \mathrm{mg} / \mathrm{mL}$. Besides that, S. typhimurium, $V$. cholerae, and $V$. parahaemolyticus had the same value for MIC and MBC, meaning this bacteria can be inhibited and killed at the same concentration of plant extract. This result showed that Gram-positive bacteria were easier to inhibit compared to Gram-negative ones. Gram-negative bacteria have a hydrophilic outer membrane rich in lipopolysaccharide molecules. Therefore it serves as a penetration barrier towards macromolecules [29]. Although this description is widely accepted, and accepted for many essential oils, some researchers have stated that the Gram distinction may have little relation to growth inhibition and some herbs are equally effective against both groups of bacteria [30]. However, the outer membrane is not completely impermeable as there are porin proteins present in this layer that can create channels large enough to allow restricted passage of molecules with a molecular mass below $600 \mathrm{Da}$, such as substituted phenolics in herb extracts and essential oils, allowing their slow penetration into the periplasmic space and the cytoplasmic membrane [31]. Thus it is possible that over a longer contact time the active compounds present in leaves extract would have the same effect on Gram-negative and Gram-positive bacteria [32]. Besides that, the Euphorbia hirta extract showed lower antimicrobial activity on E. coli compared to S. polyanthum extract with the MIC value of $3.13 \mathrm{mg} / \mathrm{mL}$ [33]. According to Rand et al. [34], S. polyanthum extract demonstrated better bactericidal and bacteriostatic properties compared to $B$. oleracea extract where MIC and MBC value of $S$. aureus, E. coli, $P$. aeruginosa, and $K$. pneumoniae were $100 \mathrm{mg} / \mathrm{mL}$ and $400 \mathrm{mg} / \mathrm{mL}, 300 \mathrm{mg} / \mathrm{mL}$ and $400 \mathrm{mg} / \mathrm{mL}, 100 \mathrm{mg} / \mathrm{mL}$ and $200 \mathrm{mg} / \mathrm{mL}$, and $100 \mathrm{mg} / \mathrm{mL}$ and $400 \mathrm{mg} / \mathrm{mL}$, respectively. Moringa oleifera seed extract displayed weaker antibacterial activity compared to $S$. polyanthum with MIC values $>4 \mathrm{mg} / \mathrm{mL}$ on $E$. coli, $P$. aeruginosa, and S. typhimurium [35]. Moreover, S. polyanthum also shows good antibacterial effect compared to garlic and ginger extract. Based on Smith-Palmer et al. [36], MIC and $\mathrm{MBC}$ of garlic and ginger extract on L. monocytogenes, E. coli and $S$. aureus were $>1 \%$ whereas $S$. polyanthum gave bacteriostatic and bactericidal effect between $0.063 \%$ and $0.125 \%$ against the same bacteria strains. On the other hand, S. polyanthum and Syzygium aromaticum (clove) showed quite similar antibacterial activity. Inhibition zones of $S$. aromaticum against $E$. coli, L. monocytogenes, and $S$. aureus were 9.7, 8.4, and $8.0 \mathrm{~mm}$, respectively. Meanwhile the MIC values were $0.04 \%, 0.03 \%$, and $0.04 \%$ on the same pathogens. Besides that, Syzygium cumini showed no antimicrobial activity against $E$. coli and $K$. pneumoniae; however, it is effective against $S$. aureus with $9.00 \mathrm{~mm}$ shown in inhibition zone [37]. Therefore, S. cumini had lower antibacterial activity compared to $S$. polyanthum extract in terms of disk diffusion test. According to Chikowe et al. [38], Syzygium forte, Syzygium francisii, Syzygium moorei, Syzygium puberulum, and S. wilsonii illustrated weaker antibacterial activity compared to S. polyanthum where there was no inhibition zone against P. mirabilis and S. aureus. However, S. francisii, S. moorei, and $S$. wilsonii showed higher inhibition zone against E. coli compared to $S$. polyanthum extract. On the other hand, all the tested Syzygium spp. gave lower antibacterial activity against E. coli compared to $S$. polyanthum in terms of MIC value except $S$. francisii with $0.256 \mathrm{mg} / \mathrm{mL}$. Apart from that, 


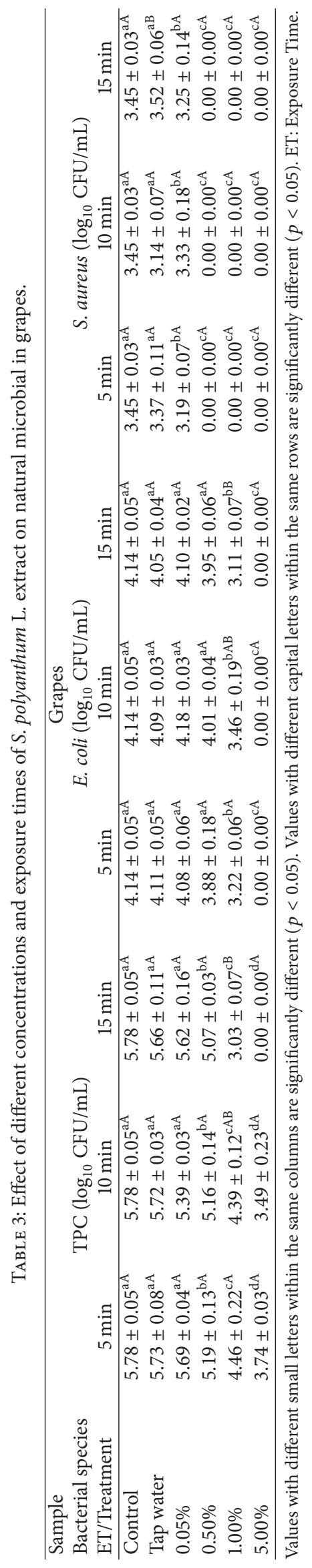


TABLE 4: Sensory attributes acceptability of treated grapes with S. polyanthum L. extract.

\begin{tabular}{lcccrr}
\hline Attributes & Tap water & $0.05 \%$ & $0.50 \%$ & $1.00 \%$ & $5.00 \%$ \\
\hline Colour & $8.49 \pm 0.88^{\mathrm{a}}$ & $8.16 \pm 1.12^{\mathrm{a}}$ & $8.10 \pm 1.08^{\mathrm{a}}$ & $7.65 \pm 0.80^{\mathrm{a}}$ & $7.81 \pm 1.88^{\mathrm{a}}$ \\
Odour & $8.59 \pm 1.65^{\mathrm{a}}$ & $7.11 \pm 1.11^{\mathrm{a}}$ & $7.53 \pm 0.82^{\mathrm{a}}$ & $7.63 \pm 1.90^{\mathrm{a}}$ & $7.25 \pm 0.70^{\mathrm{a}}$ \\
Texture & $7.04 \pm 0.89^{\mathrm{a}}$ & $7.10 \pm 0.94^{\mathrm{a}}$ & $6.87 \pm 1.02^{\mathrm{a}}$ & $7.68 \pm 0.84^{\mathrm{a}}$ & $6.84 \pm 2.10^{\mathrm{a}}$ \\
Overall acceptability & $7.24 \pm 1.40^{\mathrm{a}}$ & $7.02 \pm 1.51^{\mathrm{a}}$ & $7.13 \pm 0.95^{\mathrm{a}}$ & $7.71 \pm 1.79^{\mathrm{a}}$ & $7.28 \pm 1.84^{\mathrm{a}}$ \\
\hline
\end{tabular}

Mean values \pm standard deviation with different small letters in the same row have significance different $(p<0.05)$.

S. polyanthum had higher antibacterial activity against $K$. pneumoniae than S. forte, S. francisii, S. moorei, S. puberulum, and S. wilsonii.

Generally, different crude extracts show different antibacterial level among different microbes tested. These inconsistencies might be due to the different expression of the bioactive compounds present in the extracts. As suggested by Cowan [39], essential oils and polyphenolic compounds exhibited different bacteriostatic and bactericidal effect on bacterial strains. Therefore, minimum inhibitory concentration (MIC) is the parameter commonly used to guide the selection on the antimicrobial agent used in treatment by predicting their efficacy at a standard inoculum approximately $10^{6} \mathrm{CFU} / \mathrm{mL}$ after an incubation period of $18-24$ hours [18]. However, MIC only provides limited information on the kinetics of the antimicrobial action. Due to this limitation, time-killing assay was performed in order to find the correlation between the rate of bactericidal activity with the incubation time and concentration of antimicrobial agent [32].

Figures 1(a) and 1(b) showed that both L. monocytogenes and $P$. aeruginosa had been completely killed at $4 \mathrm{x}$ MIC in 1hour incubation with 2.52 and $5.00 \mathrm{mg} / \mathrm{mL}$ of $S$. polyanthum leaves extract, respectively. These two strains were killed earlier compared to others. However finding by Penduka and Okoh [40] stated that L. monocytogenes can be killed completely with $0.314 \mathrm{mg} / \mathrm{mL}$ of crude Garcinia kola seed methanol extract in 0.5 hours of incubation. Therefore this finding suggested that $S$. polyanthum leaves extract might possess lower antibacterial activity against $L$. monocytogenes. In other case, according to Alwash et al. [41], Melastoma malabathricum extract had been reported to be able to kill completely $P$. aeruginosa at concentration $1.56 \mathrm{mg} / \mathrm{mL}$ within 8 hours. The comparison was hard to evaluate as both extracts are effective in completely killing $P$. aeruginosa at different concentration and incubation time. Generally, more concentrated extract will be able to kill bacteria in short period.

E. coli, S. aureus, V. cholerae, and V.parahaemolyticus had been killed at $4 \mathrm{x}$ MIC within 4 hours as shown in Figures 2(a), 2(b), 2(c), and 2(d). Five $\mathrm{mg} / \mathrm{mL}$ extract had been used to kill E. coli completely in 4 hours. In contrast, Mamman et al. [42], had reported the bactericidal activity of Azadirachta indica extract on E. coli strain was at concentration $250 \mathrm{mg} / \mathrm{mL}$. Therefore, results from this study revealed that $S$. polyanthum leaves extract is a good antibacterial source against $E$. coli strain. According to Witkowska et al. [29], the bactericidal effect of sage extract on $S$. aureus was at concentration > $40 \mathrm{mg} / \mathrm{mL}$ for 24 hours of incubation time. In addition, rosemary and clove extracts were able to kill $S$. aureus completely at 5 and $10 \mathrm{mg} / \mathrm{mL}$ concentration for 4 and 6 hours of incubation time, respectively. However, from this finding, $S$. polyanthum leaves extract only took 4-hour incubation to kill $S$. aureus completely at concentration $2.52 \mathrm{mg} / \mathrm{mL}$. In comparison, $S$. polyanthum leaves have better bacterial effect against $S$. aureus compared to sage, rosemary, and clove extract. Furthermore, S. aureus was Gram-positive bacteria where the membrane structure was easier to disrupt compared to Gram-negative bacteria. From finding by Kwieciński et al. [43], it stated that $S$. aureus can be killed within $15 \mathrm{~min}$ with $1 \%(\mathrm{v} / \mathrm{v})$ of tea tree oil while El-Farmawi et al. [44] showed that methicillin-resistant $S$. aureus can be killed during 2-4 hours of incubation with cinnamon and green tea extract at concentration $300 \mu \mathrm{l} / \mathrm{mL}$ and $200 \mu \mathrm{l} / \mathrm{mL}$, respectively. In conclusion, $S$. polyanthum leaves extract had a weaker bactericidal effect as compared to tea tree oil, cinnamon, and green tea extracts. The time-kill plot obtained for $V$. cholerae and $V$. parahaemolyticus strains exhibited bactericidal end points which were at 4x MIC after 4-hour incubation. However, the population of both pathogens was reduced approximately to $3 \log$ at 2x MIC after 4 hours. Penduka and Okoh [40] reported that $69 \%$ of $V$.parahaemolyticus was killed at $5 \mathrm{mg} / \mathrm{mL}$ after 2-hour incubation using Garcia kola seed methanol extract. Therefore, S. polyanthum leaves have a quite similar bactericidal effect with G. kola seed extract where $>50 \% V$. cholerae and V. parahaemolyticus' population were completely killed at same concentration and incubation time.

On the other hand, the populations of $K$. pneumoniae, $P$. mirabilis, and $S$. typhimurium were only reduced to $<3 \log$ after 4-hour incubation as shown in Figures 3(a) and 3(b). According to Supardy et al. [45], extract able to reduce bacterial cell less than $3 \log$ was indicated as having bacteriostatic effect. Furthermore, 3 log was the minimum level of microbial population to cause infection in human. According to ElFarmawi et al. [44], K. pneumoniae can be killed within 6 to 8 hours of incubation with cinnamon and green tea extract at concentrations $500 \mu \mathrm{l} / \mathrm{mL}$ and $300 \mu \mathrm{l} / \mathrm{mL}$, respectively. Its means $S$. polyanthum leaves had a quite weaker antibacterial activity compared to cinnamon. Research by Rajeh et al. [46] reported the bactericidal activity of Euphorbia hirta extract on $P$. mirabilis was at concentration $50 \mathrm{mg} / \mathrm{mL}$ at 24 -hour incubation. Muniandy et al. [47] stated that concentration $1.08 \mathrm{mg} / \mathrm{mL}$ of Coleus aromaticus extract can completely kill P. mirabilis within 24 hours of incubation time. On the other hand, Konaté et al. [48], reported the bactericidal effect of Sida alba extract on $P$. mirabilis at concentration $0.05 \mathrm{mg} / \mathrm{mL}$ within 6 hours of incubation. Results revealed 
that $S$. polyanthum leaves possess better antibacterial agent compared to E. hirta and C. aromaticus extracts; however this leaves extract showed lower bactericidal effect compared to $S$. alba. Foster [49] stated that Salmonella spp. had the ability to adapt in wide range of conditions including ability to grow in various $\mathrm{pH}$ and temperatures. Besides that, Mandal et al. [50] reported the reduction of Salmonella spp. until $2.19 \mathrm{log}$ at concentration $0.512 \mathrm{mg} / \mathrm{mL}$ of Camelia sinensis extract within 24 hours of incubation time. Similarly, in this research, Salmonella spp. only reduced to $3 \log$ and did not completely get killed after treatment with $S$. polyanthum leaves extract in 4-hour incubation. This showed that S. polyanthum had better antibacterial activity against Salmonella spp. compared to $C$. sinensis where the population reduction took only about 4 hours.

Increasing of plant extract's concentration will lead to diffusion into membrane cell thus causing membrane destruction [51]. In addition, the killing activity of S. polyanthum leaves extract was concentration-dependent. According to Miksusanti et al. [52], at higher concentration of extract, the membrane becomes leaky to cytoplasmic components which lead to cell death. It was also speculated that high concentrations of $S$. polyanthum leaves extract contribute to rapid killing of the microorganism because of the serious loss of membrane integrity and degenerative cell wall. In order to kill the microorganisms, leaves extract needs to bind, occupy, and remain at the target site for sufficient period of time to prevent the metabolic process and interfere with the chemical reactions of the bacteria. In addition, the increasing of plant extract can saturate the target site and cause rapid bactericidal effect [53]. The hydrophobicity of plants extract and their bioactive compounds contribute in the breaking down of the membrane cells lipid and make them more permeable for the penetration [54]. Furthermore, the bioactive compounds in extract may inhibit the synthesis of essential metabolites (folic acid) by preventing the enzymatic reaction. The protein synthesis in the microorganisms also can be inhibited if the bioactive compounds interfere and change the shape of ribosome. The interference can lead to misreading of the genetic code on the mRNA [55].

Action modes of extract against tested strains were observed as shown in Figures 4 and 5. The treated $K$. pneumoniae showed that the cell was ruptured and shrunk. This observation was supported by dos Santos et al. [56], where the electron-dense particles which stayed packed in cytoplasm before were dispersed and result in an empty hollow in cytoplasm. This indicated that cytoplasm's compartment was released acrossed the cell wall. Study conducted by Supardy et al. [45] also reported the damaged and distorted K. pneumoniae cell after treating with $0.5 \mathrm{mg} / \mathrm{mL}$ of Halimeda discoidea extract for 12,24 , and 36 hours of treatment. The same result also were obtained by Rajeshwari et al. [57] where the morphology of K. pneumoniae showed unusual shapes of expanding, swelling, shrinking, and other multiple disorientations that were absent in the control sets after treating with $H$. discoidea extract. In addition, the same phenomenon was reported by Derakhshan et al. [58] who treated the K. pneumoniae with the cumin (Cuminum cyminum L.) herb extract. However, not all shrunk cells after treatment represent cells death. Some of them decrease their cell surface area as the way of adaptation, in order to minimize the target site for antimicrobial compounds to attach on them [45]. However, constant exposure of plant extract with increasing of concentration and extended time treatment will eventually kill the cells [29]. Generally, the results showed the shrinkage and deformation of the cells proved that the cells were under a suppressive and stressful environment. From the results, the prompt antibacterial action on the cells was seen to specifically attack the cell membrane components. Moreover, the treated cell of $S$. aureus also showed morphology changes. The grape-like cluster morphology of $S$. aureus was altered after the treatment. Disruptions with release of intracellular material associated with $S$. aureus cells losing their cytoplasm (empty and flaccid cells) were also observed. The distortion of the physical structure of the cell could cause the expansion and destabilization of the membrane and increase membrane fluidity, which in turn increases the passive permeability and manifests itself as a leakage of various vital intracellular constituents, such as ions, ATP, nucleic acids, sugars, enzymes, and amino acids. This observation suggested that the ionic interactions between the cationic polymers and negatively charged lipopolysaccharides (as lipoteichoic acid, a component of the thick peptidoglycan layer of Gram-positive bacteria) in the outer membrane can be responsible for the growth inhibition and lysis, through blockage of important nutrients flow such as $\mathrm{Ca}^{+2}$ and $\mathrm{Mg}^{+2}$ ion entering the cell [59].

Fresh food including fruit and vegetables may harbour a variety of microbes which priory originating from the environment where they grew. The microbes will keep growing along the postharvest handling and food processing and caused spoilage to the foods if no proper decontamination methods applied [60]. The growing and survival of these microbes with prolonged time especially during storage period will spoil the foods and cause foodborne illness when consumed by people outside. As reported by Chang and Fang [61], the survivability of E. coli O157:H7 and S. typhimurium in shredded lettuce within 10-12 days imposed a potential health risk to consumers. In this study, treatment with tap water is referring to the common washing methods applied by household. There were some researchers who reported the capability of tap water to reduce the total bacterial count around 2 to $3 \log _{10} \mathrm{CFU} / \mathrm{mL}[62,63]$. However, in this study, the treatment with tap water only showed slight reduction compared to previous study. Brackett [64] had reported that the use of tap water for washing cannot completely remove the bacterial populations on food materials. Besides, there are limitations of using tap water in washing food materials which is due to the presence of chlorine residues in treated tap water. Chlorine residues have become a concern in food safety due to their potentiality to produce carcinogenic compounds such as trihalomethanes, haloacetic acids, haloketones, and chloropicrin when reacting with organic matter [65]. As stated by Gill and Badoni [66], reusing of processing water as sanitizer will make the tap water another source of cross-contamination. In this study, the bacterial reduction in treated grapes fruit was proportional with the increasing of $S$. polyanthum extract concentration and 
soaking time. Research was in the similar of Abadias et al. [67] who also reported the reductions of microbial populations were increased as the concentration of sanitizer and washing time increased. However, study conducted by Tornuk et al. [68] proved that the ability of thyme sanitizer was affected by extract concentration while different exposure time did not give significant reduction on the bacterial populations in apple fruits. Therefore, the relative influence in terms of microbial inactivation was tap water $<0.05 \%<0.50 \%<1.00$ $<5.00 \%$.

As stated by Vilgis [69], the ideal sanitizer is when the panellists are unable to recognize the difference between treated and nontreated samples which gives the meaning of not much change occurring before or after the treatment was applied. Study reported by Kumudavally et al. [70] reported the effectiveness of clove extract on reducing the pathogenic microflora in fresh mutton until 4-day treatment at $25 \pm 2{ }^{\circ} \mathrm{C}$, at the same time giving no adverse effect on physical and sensory qualities. In correlation with that, Solomon et al. [71] had reported the organoleptic and chemical evaluations of suya (boneless meat pieces) after treating with basil extract for 30, 60, 90, and 120 mins. In their sensory analysis part, authors reported that the suya soaked with basil extracts enhances eating quality as it improved the flavour of meat. However, most of the panellists were not satisfied in terms of the final colour of treated suya (brownish green colour). In this study, grapes were accepted by panellist even after treating with highest concentration of extract (5\%). From this observation it can be concluded that, generally, the treated samples which had been exposed to highest concentration and longest exposure time were accepted by panellist. That means $S$. polyanthum extract did not affect or change the physical characteristics of food samples after exposure to highest concentration of extract at maximum time of exposure.

Antimicrobial activity of herbs and spices varies widely, depending on the several factors including spices type, test medium, and types of pathogens. Moreover, microorganisms differ in their resistance to different types of spices and herbs. According to Kalemba and Kunicka [72], active components of herbs at low concentrations may interact synergistically with other factors including sodium chloride, acids, and preservatives to increase preservation. However, antimicrobial activity of herb derived has been reported to diminish during food processing [73]. Therefore, further studies on the efficacy of these natural antimicrobial agents in a range of food products as well as evaluation of potential interactions of antimicrobial compounds with components of food matrices such as fats, carbohydrates, and proteins are required.

\section{Conclusion}

In conclusion, susceptibility test is very important step in the screening of antibacterial activity of plant material. From the result, $S$. polyanthum leaves had antibacterial activity against wide spectrum of foodborne pathogens and are able to reduce microflora count in fresh fruits. Therefore the plant might be promoted to further tests towards its evaluation as a sanitizer or preservative in wide range of foods.

\section{Conflicts of Interest}

All authors state that they have no conflicts of interest.

\section{Acknowledgments}

The study was supported by Penelitian Fundamental-FRGS Fasa 2-2014 to Yaya Rukayadi with no. FRGS/2/2014/SG05/ $\mathrm{UPM} / 02 / 2$.

\section{References}

[1] J. Meng and M. P. Doyle, "Emerging and evolving microbial foodborne pathogens," Bulletin de l'Institut Pasteur, vol. 96, no. 3, pp. 151-163, 1998.

[2] G. K. Adak, S. M. Long, and S. J. O’Brien, “Trends in indigenous foodborne disease and deaths, England and Wales: 1992 to 2000," Gut, vol. 51, no. 6, pp. 832-841, 2002.

[3] G. W. Gould, "Methods for preservation and extension of shelf life," International Journal of Food Microbiology, vol. 33, no. 1, pp. 51-64, 1996.

[4] C. R. Kiessling, J. H. Cutting, M. Loftis, W. M. Kiessling, A. R. Datta, and J. N. Sofos, "Antimicrobial resistance of food-related Salmonella isolates, 1999-2000," Journal of Food Protection, vol. 65, no. 4, pp. 603-608, 2002.

[5] D. L. Zink, "The impact of consumer demands and trends on food processing.," Emerging Infectious Diseases, vol. 3, no. 4, pp. 467-469, 1997.

[6] M. Turgis, J. Han, S. Caillet, and M. Lacroix, "Antimicrobial activity of mustard essential oil against Escherichia coli O157:H7 and Salmonella typhi," Food Control, vol. 20, no. 12, pp. 10731079, 2009.

[7] M. A. Gatto, A. Ippolito, V. Linsalata et al., "Activity of extracts from wild edible herbs against postharvest fungal diseases of fruit and vegetables," Postharvest Biology and Technology, vol. 61, no. 1, pp. 72-82, 2011.

[8] K. Das, R. K. S. Tiwari, and D. K. Shrivastava, “Techniques for evaluation of medicinal plant products as antimicrobial agent: current methods and future trends," Journal of Medicinal Plants Research, vol. 4, no. 2, pp. 104-111, 2010.

[9] E. Kato, R. Nakagomi, M. D. P. T. Gunawan-Puteri, and J. Kawabata, "Identification of hydroxychavicol and its dimers, the lipase inhibitors contained in the Indonesian spice, Eugenia polyantha," Food Chemistry, vol. 136, no. 3-4, pp. 1239-1242, 2013.

[10] S. Perumal, R. Mahmud, S. P. Piaru, L. W. Cai, and S. Ramanathan, "Potential antiradical activity and cytotoxicity assessment of Ziziphus mauritiana and syzygium polyanthum," International Journal of Pharmacology, vol. 8, no. 6, pp. 535-541, 2012.

[11] A. Sumono and A. S. Wulan, "The use of bay leaf (Eugenia polyantha Wight) in dentistry," Dental Journal, vol. 41, no. 3, pp. 147-150, 2015.

[12] A. Ismail, M. Mohamed, S. A. Sulaiman, and W. A. N. Wan Ahmad, "Autonomic nervous system mediates the hypotensive effects of aqueous and residual methanolic extracts of Syzygium polyanthum (Wight) Walp. var. polyanthum leaves in anaesthetized rats," Evidence-Based Complementary and Alternative Medicine, vol. 2013, Article ID 716532, 16 pages, 2013.

[13] P. W. Grosvenor, A. Supriono, and D. O. Gray, "Medicinal plants from Riau Province, Sumatra, Indonesia. Part 2: antibacterial 
and antifungal activity," Journal of Ethnopharmacology, vol. 45, no. 2, pp. 97-111, 1995.

[14] M. E. Guynot, S. Marín, L. Setó, V. Sanchis, and A. J. Ramos, "Screening for antifungal activity of some essential oils against common spoilage fungi of bakery products," Food Science and Technology International, vol. 11, no. 1, pp. 25-32, 2005.

[15] K. Y. Lau, N. S. Zainin, F. Abas, and Y. Rukayadi, "Antibacterial and sporicidal activity of Eugenia polyanthaWight against Bacillus cereusand Bacillus subtilis," International Journal of Current Microbiology and Applied Science, vol. 3, no. 12, pp. 499-510, 2013.

[16] Y. Rukayadi, J.-S. Shim, and J.-K. Hwang, "Screening of Thai medicinal plants for anticandidal activity," Mycoses, vol. 51, no. 4, pp. 308-312, 2008.

[17] N. Varghese and P. P. Joy, "Culture preservation techniques," Microbiology Laboratory Manual, p. 31, 2014.

[18] Clinical and Laboratory Standards Institute (CLSI), Reference method for dilution antimicrobial susceptibility tests for bacteria that grow aerobically. Approved standard M7-A6, National Committee for Clinical Laboratory Standards, Wayne, Penn, USA, 2012.

[19] E. L. de Souza, T. L. M. Stamford, and E. D. O. Lima, "Sensitivity of spoiling and pathogen food-related bacteria to origanum Vulgare L. (lamiaceae) essential oil," Brazilian Journal of Microbiology, vol. 37, no. 4, pp. 527-532, 2006.

[20] N. A. H. Yusoff, N. F. Noor, and Y. Rukayadi, "Effects of Cosmos caudatus Kunth. (Ulam raja) extract on microflora in raw chicken meat microflora in raw chicken meat," International Journal Current Microbiology and Applied Science, vol. 4, no. 2, pp. 426-435, 2010.

[21] I. M. Brasil, C. Gomes, A. Puerta-Gomez, M. E. Castell-Perez, and R. G. Moreira, "Polysaccharide-based multilayered antimicrobial edible coating enhances quality of fresh-cut papaya," LWT-Food Science and Technology, vol. 47, no. 1, pp. 39-45, 2012.

[22] O. A. Fatoki and D. A. Onifade, "Use of plant antimicrobials for food preservation," International Journal of Veterinary and Agricultural Engineering, vol. 7, no. 12, pp. 1110-1113, 2013.

[23] R. J. Marriott, "Greener chemistry preparation of traditional flavour extracts and molecules," Agro Food Industry Hi-Tech, vol. 21, no. 2, pp. 46-48, 2010.

[24] P. A. Lambert, "Cellular impermeability and uptake of biocides and antibiotics in gram-positive bacteria and mycobacteria," Journal of Applied Microbiology, vol. 92, pp. 46S-54S, 2002.

[25] M. Othman, H. S. Loh, C. Wiart, T. J. Khoo, K. H. Lim, and K. N. Ting, "Optimal methods for evaluating antimicrobial activities from plant extracts," Journal of Microbiological Methods, vol. 84, no. 2, pp. 161-166, 2011.

[26] J. Gangoué-Piéboji, N. Eze, A. N. Djintchui et al., "The invitro antimicrobial activity of some traditionally used medicinal plants against beta-lactam-resistant bacteria," The Journal of Infection in Developing Countries, vol. 3, no. 9, pp. 671-680, 2009.

[27] A. K. Abbas, S. Marjan, K. Masoud, and J. Sharnaz, "Stability of antibacterial activity of Chlorhexidine and Doxycycline in bovine root dentine," Journal of Research in Pharmacy Practice, vol. 3, no. 1, pp. 19-22, 2014.

[28] C. Gupta, G. P. Amar, and C. U. Ramesh, "Antibacterial activity of amchur (dried pulp of unripe Mangiferaindica) extracts on some indigenous oral microbiota causing dentalcaries," Ethnobotanical Leaflets, vol. 13, no. 5, pp. 611-617, 2009.
[29] A. M. Witkowska, D. K. Hickey, M. Alonso-Gomez, and M. Wilkinson, "Evaluation of antimicrobial activities of commercial herb and spice extracts against selected food-borne bacteria," Journal of Food Research (JFR), vol. 2, no. 4, p. 37, 2013.

[30] P. Kotzekidou, P. Giannakidis, and A. Boulamatsis, "Antimicrobial activity of some plant extracts and essential oils against foodborne pathogens in vitro and on the fate of inoculated pathogens in chocolate," LWT - Food Science and Technology, vol. 41, no. 1, pp. 119-127, 2008.

[31] T. Abee, L. Krockel, and C. Hill, "Bacteriocins: modes of action and potentials in food preservation and control of food poisoning," International Journal of Food Microbiology, vol. 28, no. 2, pp. 169-185, 1995.

[32] M. Mueller, A. De La Peña, and H. Derendorf, "Issues in Pharmacokinetics and Pharmacodynamics of Anti-Infective Agents: Kill Curves versus MIC," Antimicrobial Agents and Chemotherapy, vol. 48, no. 2, pp. 369-377, 2004.

[33] E.-M. M. Abubakar, "Antibacterial activity of crude extracts of Euphorbia hirta against some bacteria associated with enteric infections," Journal of Medicinal Plants Research, vol. 3, no. 7, pp. 498-505, 2009.

[34] R. H. Rand, A. S. Abdulamir, L. S. Vern et al., "Inhibition of growth of highly resistant bacterial and fungal pathogens by a natural product," The Open Microbiology Journal, vol. 5, pp. 96106, 2011.

[35] A. Bukar, A. Uba, and T. Oyeyi, "Antimicrobial profile of moringa oleifera lam. Extracts against some food-borne microorganisms," Bayero Journal of Pure and Applied Sciences, vol. 3, no. 1, pp. 43-48, 2010.

[36] A. Smith-Palmer, J. Stewart, and L. Fyfe, "Antimicrobial properties of plant essential oils and essences against five important food-borne pathogens," Letters in Applied Microbiology, vol. 26, no. 2, pp. 118-122, 1998.

[37] G. F. de Oliveira, N. A. J. C. Furtado, A. A. Da Silva Filho et al., "Antimicrobial activity of Syzygium cumini (Myrtaceae) leaves extract," Brazilian Journal of Microbiology, vol. 38, no. 2, pp. 381384, 2007.

[38] G. Chikowe, L. Mpala, and I. E. Cock, "Antibacterial activity of selected Australian Syzygium species," Pharmacognosy Communications, vol. 3, no. 4, pp. 1-7, 2013.

[39] M. M. Cowan, "Plant products as antimicrobial agents," Clinical Microbiology Reviews, vol. 12, no. 4, pp. 564-582, 1999.

[40] D. Penduka and A. I. Okoh, "In vitro antilisterial properties of crude methanol extracts of Garcinia kola (Heckel) seeds," The Scientific World Journal, vol. 2012, Article ID 694828, 7 pages, 2012.

[41] M. S. Alwash, N. Ibrahim, and W. Y. Ahmad, "Identification and mode of action of antibacterial components from Melastoma Malabathricum linn leaves," American Journal of Infectious Diseases, vol. 9, no. 2, pp. 46-58, 2013.

[42] P. H. Mamman, W. P. Mshelia, S. C. Susbatrus, and S. Sambo, "Antibacterial effects of crude extract of Azadirachtaindica against Escherichia coli, Salmonella spp. and Staphylococcus aureus," International Journal of Medicine and Medical Sciences, vol. 5, no. 1, pp. 14-18, 2013.

[43] J. Kwieciński, S. Eick, and K. Wójcik, "Effects of tea tree (Melaleuca alternifolia) oil on Staphylococcus aureus in biofilms and stationary growth phase," International Journal of Antimicrobial Agents, vol. 33, no. 4, pp. 343-347, 2009.

[44] D. El-Farmawi, Z. Olama, and H. Holail, "The antibacterial effect of some natural bioactive materials against Klebsiella 
pneumoniae and MRSA," International Journal of Current Microbiology Applied Science, vol. 3, no. 3, pp. 576-588, 2014.

[45] N. A. Supardy, D. Ibrahim, S. F. Sulaiman, and N. A. Zakaria, "Inhibition of Klebsiella pneumoniae ATCC 13883 cells by hexane extract of Halimeda discoidea (Decaisne) and the identification of its potential bioactive compounds," Journal of Microbiology and Biotechnology, vol. 22, no. 6, pp. 872-881, 2012.

[46] M. A. B. Rajeh, Z. Zuraini, S. Sasidharan, L. Y. Latha, and S. Amutha, "Assessment of Euphorbia hirta L. leaf, flower, stem and root extracts for their antibacterial and antifungal activity and brine shrimp lethality," Molecules, vol. 15, no. 9, pp. 60086018, 2010.

[47] K. Muniandy, Z. Hassan, and M. H. M. Isa, "Antimicrobial activity of ethanolic extract of Coleus aromaticusagainst common wound pathogens," Research Journal of Pharmaceutical, Biological and Chemical Sciences, vol. 5, no. 3, article 1286, 2013.

[48] K. Konaté, A. Hilou, J. F. Mavoungou et al., "Antimicrobial activity of polyphenol-rich fractions from Sida alba L. (Malvaceae) against co-trimoxazol-resistant bacteria strains," Annals of Clinical Microbiology and Antimicrobials, vol. 11, no. 5, pp. 26, 2012.

[49] J. W. Foster, "Low ph adaptation and the acid tolerance response of salmonella typhimurium," Critical Reviews in Microbiology, vol. 21, no. 4, pp. 215-237, 1995.

[50] S. Mandal, M. DebMandal, N. K. Pal, and K. Saha, "Inhibitory and killing activities of black tea (Camellia sinensis) extract against Salmonella enterica serovar Typhi and Vibrio cholerae O1 biotype $\mathrm{El}$ Tor serotype Ogawa isolates," Jundishapur Journal of Microbiology, vol. 4, no. 2, pp. 115-121, 2011.

[51] A. S. Thangiah, J. Obey, and N. C. Mutuku, "Phytochemical analysis of Vernoniaadoensisleaves and roots used as a traditional medicinal plant in Kenya," International Journal of Pharmaceutical and Biological, vol. 3, no. 3, pp. 46-52, 2013.

[52] Miksusanti, S. L. J. Betty, R. Syarief, B. Pontjo, and G. T. Mulyadi, "Antibacterial activity of temu kunci tuber (kaempheria pandurata) essential oil against Bacillus cereus," Medical Journal of Indonesia, vol. 18, no. 1, pp. 10-17, 2009.

[53] G. Satta, G. Cornaglia, A. Mazzariol, G. Golini, S. Valisena, and R. Fontana, "Target for bacteriostatic and bactericidal activities of $\beta$-lactam antibiotics against Escherichia coli resides in different penicillin-binding proteins," Antimicrobial Agents and Chemotherapy, vol. 39, no. 4, pp. 812-818, 1995.

[54] J. Sikkema, J. A. M. de Bont, and B. Poolman, "Mechanisms of membrane toxicity of hydrocarbons," Microbiology and Molecular Biology Reviews, vol. 59, no. 2, pp. 201-222, 1995.

[55] G. J. Tortora, B. R. Funke, and C. L. Case, "Antimicrobial Drug," in Microbiology: An Introduction, Pearson Benjamin Cumming, San Francisco, Calif, USA, 2007.

[56] E. C. G. dos Santos, C. L. Donnici, E. R. da Silva Camargos et al., "Effects of Copaifera duckei Dwyer oleoresin on the cell wall and cell division of Bacillus cereus," Journal of Medical Microbiology, vol. 62, no. 7, pp. 1032-1037, 2013.

[57] H. Rajeshwari, S. Nagveni, A. Oli, D. Parashar, and K. R. Chandrakanth, "Morphological changes of Klebsiella pneumoniae in response to Cefotaxime: a scanning electron microscope study," World Journal of Microbiology and Biotechnology, vol. 25, no. 12, pp. 2263-2266, 2009.

[58] S. Derakhshan, M. Sattari, and M. Bigdeli, "Effect of subinhibitory concentrations of cumin (Cuminum cyminum L.) seed essential oil and alcoholic extract on the morphology, capsule expression and urease activity of Klebsiella pneumoniae," International Journal of Antimicrobial Agents, vol. 32, no. 5, pp. 432436, 2008.

[59] J. Diaz-Visurraga, G. Cardenas, and A. Garcia, "Morphological changes induced in bacteria as evaluated by electron," Microscopy: Science, Technology, Applications and Education, pp. 307-315, 2010.

[60] M. R. Wachtel and A. O. Charkowski, "Cross-contamination of Lettuce with Escherichia coli O157:H7," Journal of Food Protection, vol. 65, no. 3, pp. 465-470, 2002.

[61] J.-M. Chang and T. J. Fang, "Survival of Escherichia coli O157:H7 and Salmonella enterica serovars Typhimurium in iceberg lettuce and the antimicrobial effect of rice vinegar against $E$. coli O157:H7," Food Microbiology, vol. 24, no. 7-8, pp. 745-751, 2007.

[62] D. O. Ukuku and W. F. Fett, "Method of applying sanitizers and sample preparation affects recovery of native microflora and Salmonella on whole cantaloupe surfaces," Journal of Food Protection, vol. 67, no. 5, pp. 999-1004, 2004.

[63] S. Inatsu, A. Ohsaki, and K. Nagata, "Idebenone acts against growth of Helicobacter pylori by inhibiting its respiration," Antimicrobial Agents and Chemotherapy, vol. 50, no. 6, pp. 22372239, 2006.

[64] R. E. Brackett, "Shelf stability and safety of fresh produce as influenced by sanitation and disinfection," Journal of Food Protection, vol. 55, no. 10, pp. 808-814, 1992.

[65] R. G. Klaiber, S. Baur, G. Wolf, W. P. Hammes, and R. Carle, "Quality of minimally processed carrots as affected by warm water washing and chlorination," Innovative Food Science and Emerging Technologies, vol. 6, no. 3, pp. 351-362, 2005.

[66] C. O. Gill and M. Badoni, "Recovery of bacteria from poultry carcasses by rinsing, swabbing or excision of skin," Food Microbiology, vol. 22, no. 1, pp. 101-107, 2005.

[67] M. Abadias, T. P. Cañamás, A. Asensio, M. Anguera, and I. Viñas, "Microbial quality of commercial 'Golden Delicious' apples throughout production and shelf-life in Lleida (Catalonia, Spain)," International Journal of Food Microbiology, vol. 108, no. 3, pp. 404-409, 2006.

[68] F. Tornuk, H. Cankurt, I. Ozturk, O. Sagdic, O. Bayram, and H. Yetim, "Efficacy of various plant hydrosols as natural food sanitizers in reducing Escherichia coli O157:H7 and Salmonella Typhimurium on fresh cut carrots and apples," International Journal of Food Microbiology, vol. 148, no. 1, pp. 30-35, 2011.

[69] T. A. Vilgis, "Texture, taste and aroma: multi-scale materials and the gastrophysics of food," Flavour, vol. 2, no. 12, pp. 2-5, 2013.

[70] K. V. Kumudavally, A. Tabassum, K. Radhakrishna, and A. S. Bawa, "Effect of ethanolic extract of clove on the keeping quality of fresh mutton during storage at ambient temperature (25 \pm $\left.2{ }^{\circ} \mathrm{C}\right)$," Journal of Food Science and Technology, vol. 48, no. 4, pp. 466-471, 2011.

[71] E. B. Solomon, S. Yaron, and K. R. Matthews, "Transmission of Escherichia coli O157:H7 from contaminated manure and irrigation water to lettuce plant tissue and its subsequent internalization," Applied and Environmental Microbiology, vol. 68, no. 1, pp. 397-400, 2002.

[72] D. Kalemba and A. Kunicka, "Antibacterial and antifungal properties of essential oils," Current Medicinal Chemistry, vol. 10, no. 10, pp. 813-829, 2003.

[73] N. S. Weerakkody, N. Caffin, M. S. Turner, and G. A. Dykes, "In vitro antimicrobial activity of less-utilized spice and herb extracts against selected food-borne bacteria," Food Control, vol. 21, no. 10, pp. 1408-1414, 2010. 

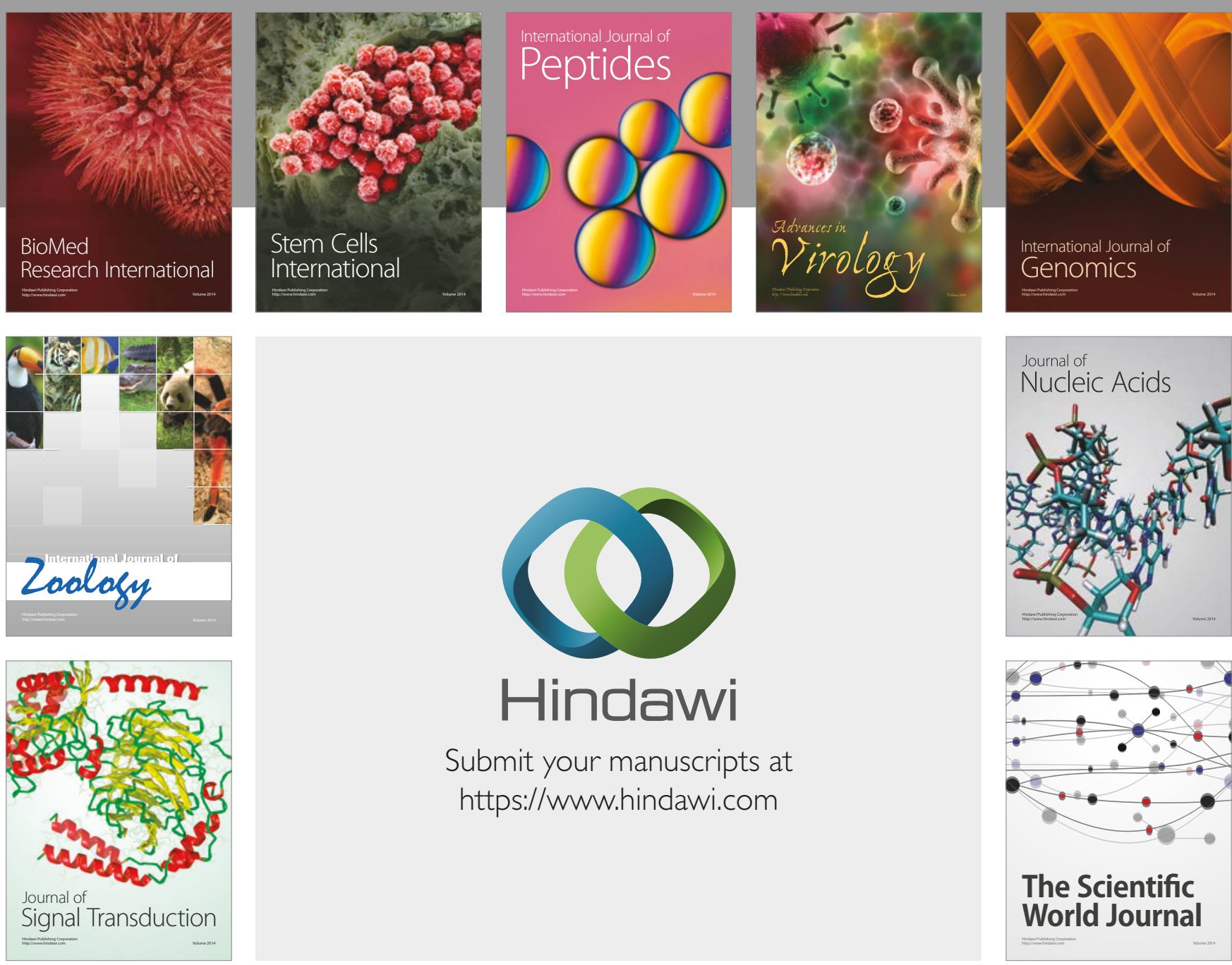

Submit your manuscripts at

https://www.hindawi.com
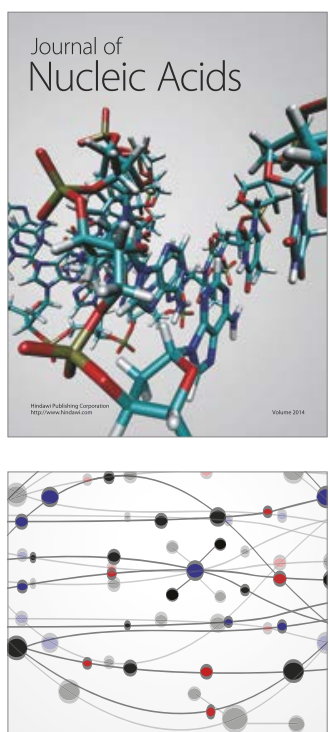

The Scientific World Journal

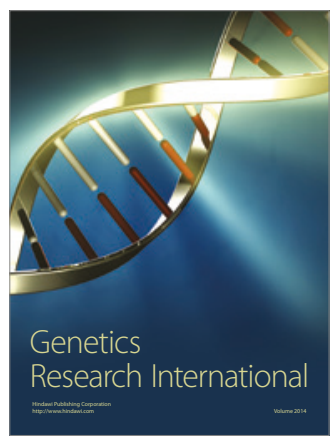

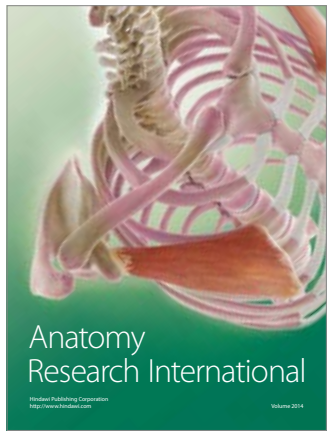

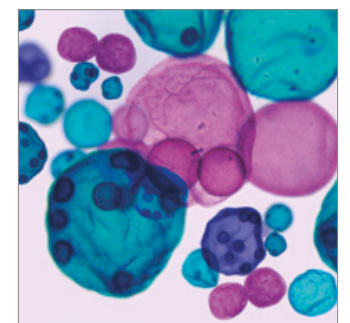

International Journal of Microbiology
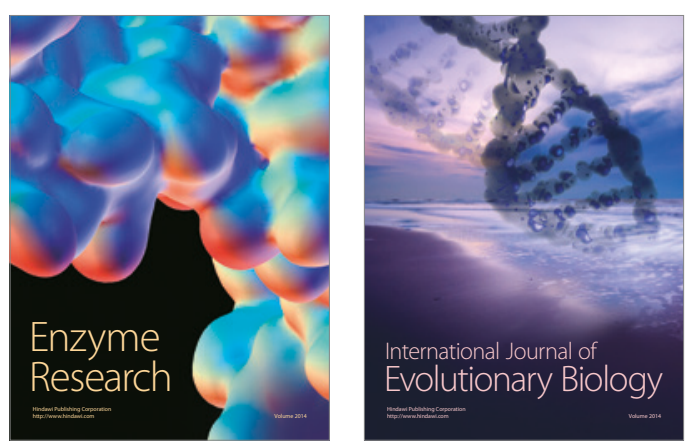
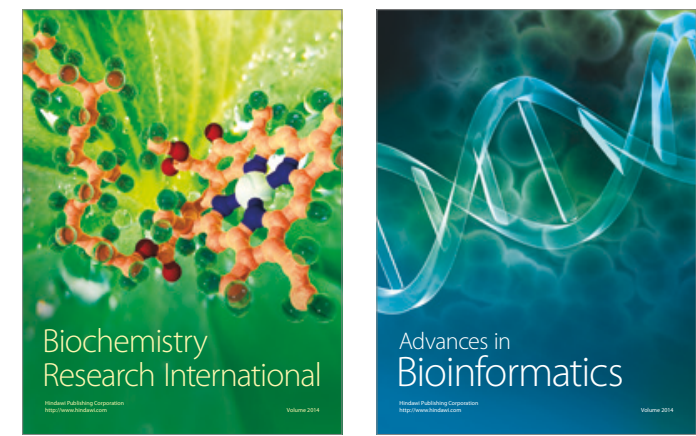

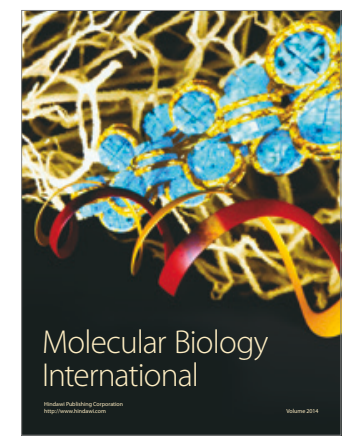

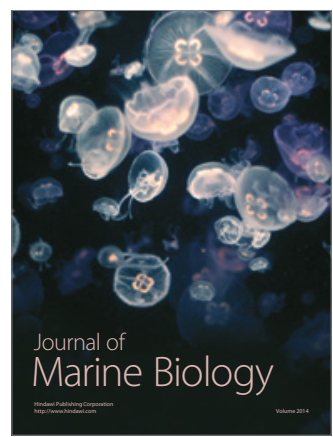

